\title{
FORMAL MENTORING INITIATIVE AS A LIKELY PANACEA TO STUDENTS' MALADAPTIVE BEHAVIOUR
}

\author{
INERHUMWUNWA, Iyobosa Mrs \\ Adolo College, Benin City. \\ iyomatth@yahoo.com
}

\begin{abstract}
The concept of formal mentoring may be new to this part of the world, but this paper shows its far reaching effect. Mentoring is a developmental, caring, sharing and helping relationship where one person invests time, know how, and effort in enhancing another person's growth, knowledge and skills, and responds to critical needs in the life of that person in ways that prepare the individual for greater productivity and achievement in life. This paper examined the problem of maladaptive behaviour in Nigeria Secondary Schools and opined that this may likely be corrected by putting in place mentoring initiatives. The initiation of formal mentoring programme would increase the number of capable hands to help guide, advice, coach, support and act as positive role models to these students. Finally, this article examined the benefits of mentoring to include the improvement of self confidence and self-esteem, which can in turn help solve students' maladaptive behaviour.
\end{abstract}

Key Words: Formal mentoring initiative, panacea, students, maladaptive behaviour.

\section{Introduction:}

The secondary school stage is a period of transition between childhood and adulthood in the life of the adolescent. It is a period in which the child forms a pattern of behaviour and relationships which have their life time effect (Alutu, 2007). The home, at this stage, is expected to informally educate the individual on moral behaviour acceptable to the society. It is this informal education that is complemented by the school. The effort of both the parents and the school is expected to bring forth acceptable behaviour that would in turn benefit the society. This however does not seem to be very manifest as maladaptive behaviour has become a problem in our secondary schools.

The restlessness and misbehaviour of students appear to be gaining momentum. The high hopes and expectation of parents in sending their wards to school are being dashed to pieces. This rise in 
harmful behaviour is truncating the good academic performance of our secondary school students. Egbochuku and Aihie (2007) observed that "Adolescents in the schools are engaged in maladaptive behaviours such as truancy, lying, bullying, aggression, cultism and examination malpractice." Alutu (2007) sees these maladaptive behaviour as offences that run counter to school's rules and regulations and result in indiscipline and general disorder in schools.

Many have blamed the problem on the school, others have blamed it on the parents' rush for wealth and social statuesque which has deprived them from giving their children the basic moral education. Odebunmi (2007) is of the opinion that there is no need to argue on who is to blame. He suggested that creating mentoring initiative would help salvage the situation. These mentors would help to protect and guide these students to remain focused and avoid the pit falls of negative influence.

\section{Theoretical Background}

There are lots of theories that support mentoring. One of such is the Social cognitive Development Theory of Lev. Vygotsky. Its major theme is that social interaction plays a fundamental role in the development of cognition. One of the principles that this theory rests on is the principle of the More Knowledgeable Others (MKO). The MKO refers to any one who has better understanding or a higher ability level than the learner. The MKO is usually thought of as being a teacher, coach, or older adult, but could also be a peer, a younger person or even computers.

The maladaptive behaviours in our secondary school students could be as a result of exposure to the wrong MKO. It would therefore be of help if these students could be paired with positive $\mathrm{MKO}$ in a mentoring programme in order to elicit positive and adaptable behaviour.

\section{What is Mentoring?}

Mentoring is increasingly being recognized as a powerful and effective tool in the promotion of change and development within organizations because according to Balogun \& Okurame (1999), it has enormous potential advantages, not only to the organization but also to the individual involved. In a web definition, mentoring is seen as a developmental, caring, sharing and helping relationship where one person invests time, know how, and effort in enhancing another person's growth, knowledge and skills, and responds to critical needs in the life of that person in ways that prepare the individual for greater productivity 
or achievement in life. According to Stephen and Gareth (1999), mentoring is a process where one person offers help, guidance, advice and support to facilitate the learning or development of another person. In the view of Balance Resource Pack sponsored by Fund for the Development of Teaching \& Learning, it is a confidential relationship where the mentor helps the mentee in their personal or career development, by sharing their experience and enabling the mentee to take responsibility for their development. The mentoring relationship is between a mentor and a mantee or protégé (a person guided and protected by a more experienced person). A mentor is someone who is more experienced and takes special interest in the development of another, particularly a student.

According to Stephen and Gareth (1999) the mentor:

a. Provides resources and opportunity for development

b. Assists the learner in solving problems

c. Provides role model and passes on skills

d. Provides personal support and motivation

e. Helps learner set high but achievable goal and make realistic plans

Smith (1998) sums it up by saying that the mentor's role involves providing encouragement and support, helping to build self-confidence, challenging negative attitude and offering constructive feedback.

\section{Types of mentoring}

There are two types of mentoring relationships: formal and informal. The informal relationship develops on its own between partners. Formal mentoring, on the other hand, refers to assigned relationship often associated with organizational mentoring programme designed to promote employee development or protect at risk children and youths (Wikipedea,2008). Centre for Women and Information Technology (2004) observed that formal (assigned) and informal (self selected, not assigned) mentoring has both been used for years to help protégé increase their confidence, instil a sense of responsibility, raise awareness of the importance of receiving quality education and generate both a desire and ability to succeed personally and professionally.

\section{The Need for Formal Mentoring Initiative in Secondary School}

In the opinion of American School Counsellor Association (2008), the high school is a final transition into adulthood. Students at this stage define who they are, what they do well and what they will do in the future. During the adolescent years, students are evaluating their 
strength, skills and abilities. Their greatest influence is their peer group. They are searching for a place to belong and rely on peers' acceptance and feedback. They face increased pressures regarding risk behaviour while exploring the boundaries of more acceptable behaviour and seeking meaningful relationship. They need guidance in making concrete and compounded decision/choices. According to Odebunmi (2007), those children and adolescents school drop outs or kicked out of school, always absent from school, who wish to improve on their academic performance and those who wish to become productive adults within their society need mentoring. Such categories of children and adolescents listed above are not far fetched in our school system. Thus, formal mentoring programmes in the view of Wikipedia, (2008) are designed to help promote the proper development of at risk children.

In meeting the above challenges, the school counsellor cannot work in isolation. Instead, he is integral to the success of $t$ he entire school programme. He is the Human Resource Manager who could set up a formal mentoring programme. According to Welch (1996), formal academic mentor programmes are geared to help students succeed. Academic mentors tend to carry out a blend of psychosocial and career related functions.

This mentoring initiative would increase the number of capable hands to help guide, advice, coach support, and act as positive role model to these students. The assistance of more experienced persons in this crucial developmental stage of our secondary school students would go a long way to reduce the problem of maladaptive behaviour.

Brooks (2006) suggest the form it would take to set up a mentoring programme:

- An adequate supply of suitable mentors for differing requirements

- High quality mentor training

- A skilled matching process

- Review and evaluation of the programme

\section{Benefit of Mentoring}

Educational Funding Council for England in a report observed that mentoring is of great benefit to the mentee in the following ways:

- It improves self confidence and self esteem

- Raises achievement and aspiration

- Increases motivation

- Improves performance 
Odebunmi (2007) reported some studies on mentoring initiatives as follows:

Among the mentoring facts printed in the (ADP) \#96-6670 publication of April, 1997 include studies providing data reflecting the powerful impart of a caring adult in a young person's life. Research shows $46 \%$ reduction in the initiation of alcohol use for young people in a study of Big Brother/ Big Sister programme. Further research findings by another agency reported that grades in school improve for $59 \%$ of students as a result of help from their mentors; $53 \%$ credited their mentors with improving $t$ heir ability to avoid drugs; $52 \%$ of the students improved their ability to stay out of trouble as a result of the mentoring experience.

\section{Conclusion}

Formal mentoring programme in schools is not a practice in this part of the world. But from the above success report on such programme, one would opine that it could be a panacea to the maladaptive behaviour prevalent in our secondary schools.

Formal mentoring programme should be set up in our schools. This would spell a deliberate attachment of students who are problematic to mentors who could help to act as guide and role models to them. Also, students not in the above category could be enhanced and protected by mentors for proper personal and academic development.

\section{References}

Alutu, A. N. G. (2007) Theory and Practice of Guidance and Counselling. Ibadan, Ibadan Counsellor".

Balance Project 33/99: Mentoring Resource Pack. Section 5-8: Sponsored by Fund for the Development of Teaching \& Learning: United Kingdom

Balogun, S. K. \& Okurame, E. D. (1999) Informal Mentoring Scale: Development and Validation. Journal of Educational Psychology and Sport Ethics, University Press.

American School Counsellor Association (2008) "Why Secondary School Vol. 1, pp. 16-18.

Brooks, T. (2006) Cultural Leadership Programme: Coaching and Mentoring Report. Retrieved August, 2008.

Centre for Women and Information Technology, (2004): Mentoring Tool Kit: Maryland, UMBC University in Maryland. 
Egbochuku E. O. \& Aihie N. O. (2007) "Influence of Peer Group Counselling and Family Type on the self - concept of secondary school Adolescents in Benin City. African Journal of Studies in Education vol. 3(1), pp. 48-58.

Odebunmi, A. (2007) Parenting: A cross cultural and Psychological Perspective, Abuja. Afabunmi Nigeria Limited.

Smith, J. (1998) Empowering people: How to bring out the best from your Work Force: London. Kogan page press.

Stephen, G. \& Gareth, L. (1999). Successful mentoring in a week: Hodder and Stonghton Educational, London.

Welch O. M. (1996) An examination of effective mentoring models in the Academy. (Report No. H E029160) Eric Document Reproduction Service NO. ED394464

Wikipedea (2008) Mentorship, the free encyclopaedia.

http://en.wikipedea.org/wiki/mentoring Retrieved

29/06/20098

http://www.org.au.gov/trainingadmin/entoring.pdg

.Retrieved 12/01/2009 